\title{
Anthropometric Characteristics and Health Self-Assessment of Female University Students
}

\author{
Olivera Pilipović-Spasojević, ${ }^{1}$ Nenad Ponorac, ${ }^{2}$ Mira Spremo, ${ }^{3}$ Tina Radojčić ${ }^{4}$
}

\section{Abstract}

Background/Aim: An important period in becoming a young woman is studying at the University. It is a period of taking responsibility for yourself, your health and social relationships. The abilities formed during this period directly affect one's physical and mental health. The study was undertaken in order to determine anthropometric characteristics and to evaluate the health of female students aged 19 to 22 .

Methods: An analytical population study based on a survey using a standardised SF36 self-report health test and measurement using an objective bioimpedance method with Omron BF 511 estimated 408 female students of the University of Banja Luka aged 19 to 22, based on inclusion criteria.

Results: The mean body mass index (BMI) \pm standard deviation of female students was $22.1 \pm 3.2 \mathrm{~kg} / \mathrm{m}^{2}$, with $31.80 \pm 6.47$ percent fat and $28.15 \pm 2.81$ percent muscle mass. The mean values \pm standard deviation of the SF 36 for mental health (MH) questionnaires was 60.7 \pm 24.95 and for physical health $(\mathrm{FH}) 72.21 \pm 25.89$. Conclusion: Female students have ideal BMI values. Physical health self-assessment reached higher values than the mental health self-assessment, which is probably related to mental distress and problems during studying.

Key words: student health, anthropometry, SF36 questionnaire, physical and mental health.

(1) Faculty of Medicine, University of Banja Luka, Institute of Physical Medicine and Rehabilitation "Dr Miroslav Zotović", Banja Luka, the Republic of Srpska, Bosnia and Herzegovina.

(2) Department of Physiology, Faculty of Medicine, University of Banja Luka, Banja Luka, the Republic of Srpska, Bosnia and Herzegovina.

(3) Faculty of Medicine, University of Banja Luka, Psychiatric Clinic, University Clinical Centre of the Republic of Srpska, Banja Luka, the Republic of Srpska, Bosnia and Herzegovina.

(4) Public Health Institute of the Republic of Srpska, Banja Luka, the Republic of Srpska, Bosnia and Herzegovina.

\section{Correspondence:}

OLIVERA PILIPOVIĆ-SPASOJEVIĆ E: olivera0512@gmail.com M: +387 65543003

\section{ARTICLE INFO}

Received: 17 January 2020 Revision received: 13 February 2020 Accepted: 17 February 2020

\section{Introduction}

Student population belongs to the young adult population and is in the post-adolescence period when a person has reached full maturity and development of all biological functions of the organism. ${ }^{1}$ Moving from younger to older adolescence, significant changes affect the body and psychosocial well-being of young people. ${ }^{2,3}$ Research records the occurrence of risky behavior of young people in the period of study and in a new and unfamiliar environment. ${ }^{4-7}$ During this period, young people are considered "healthy" and they do not consider their own engagement in health promotion as their priority. The transition from high school to college education is a period of taking responsibility for oneself, one's health and social relationships..$^{4,8}$ During this period, young people often resort to different types of risky behaviors such as smoking, drinking, unprotected sex and poor eating habits..$^{9-11}$ Healthcare professionals care about the health of their patients, but they also play a role in health promotion in different parts of the population and especially in the student population. The most important stages of life for physical and mental health are childhood and adolescence. It is a period when young people develop autonomy, self-control, social interaction and learning and the abilities formed during this period directly affect their physical and mental health for the rest of their lives. Half of all mental health problems in adulthood occur during or 
before adolescence..2, 12, 13 Self-assessment of the existence of mental or physical changes or presence of certain symptoms, attempts to find out to what extent one is experiencing health problems or complaining of impaired physical functioning.

The aim of this study was to determine the anthropometric characteristics and to evaluate health of female students aged 19 to 22 at the University of Banja Luka.

\section{Methods}

This observational analytical study included a survey and measurement of a sample of $408 \mathrm{fe}-$ male 1st- and 2nd- year students from various faculties of the University of Banja Luka. All students were healthy volunteers aged 19-22. Students with musculoskeletal inherited and acquired diseases, traumas and deformities of the body, acute and chronic diseases as well as with a special diet were not included. The research was approved by the Ethics Committee of the Faculty of Medicine of the University of Banja Luka (Approval Certificate No 18/4.56/18, dated 2 November 2018). All the participants were provided with a detailed oral and printed explanation of the research plan and programme and their written consents were obtained. In this research, the applicable regulations in compliance with the ethical principles of the Declaration of Helsinki were followed. For the purposes of the research, a short socio-demographic questionnaire was used. It provides personal information on the students' age, year of study, general health status. A standardised test was then used: the SF-36 self-report health questionnaire and the OMRON BF 511 digital scale for anthropometric measurements. SF-36 is a multifunctional health self-assessment questionnaire consisting of 36 questions (particles).14-16 Individual responses to all of the particle items are scored according to pre-established empirical norms, given the diagnostic value of the examiner's specific response. The health change particle is displayed separately, by frequency distribution. The SF-36 measures the subjective sense of health across the eight different dimensions of health: physical functioning, restriction due to physical difficulties, physical pain, perception of general health, vitality, social functioning, restriction due to emotional distress, mental/ mental health. The SF-36 questionnaire is based on two general health concepts: physical and mental health, although the dimensions selected represent multiple health indicators, including: behavioural function and dysfunction, suffering and well-being, objective reports and subjective evaluations, and self-evaluation of favourable and unfavourable general health statuses.

OMRON BF 511 is a high-precision digital medical scale: after entering height, age and gender data, the subject stands barefoot without excess clothing on the scale measuring body mass and calculating the body mass index (BMI), body fat percentage, visceral fat (adipose tissue around the internal organs) and the percentage of skeletal muscle. Based on the measurement of the body bioimpedance, the body composition is calculated and recorded on the display. The accuracy of the device when measuring body mass from 40.0 to $150.0 \mathrm{~kg}$ is $\pm 1 \%$. The measurement results are categorised as follows: a) BMI is divided into 6 categories: malnutrition (BMI $\leq 18.5$ ); ideal mass (18.5 to 24.9); overweight (BMI: 25-29.9); mild obesity (BMI: 30-34.9); severe obesity (BMI: 35-39.9); extreme obesity (BMI $\geq 40)$; b) Skeletal muscle and adipose tissue percentage of the total body mass, according to the known percentage of adult females aged 18-39, is divided into 4 categories: low percentage o to <24.3\%; normal percentage: $24.3-30.3$ $\%$; high percentage: $30.4-35.3 \%$ and with very high percentage $\geq 35.4 \%$ of total body mass. The measurement was always carried out by the same researcher, using the same instrument to reduce the erroneous measurements and the respondent verified that she had not consumed food and drink for at least 3 hours before the measurement, without intense physical activity for the last 12 hours, with a urinary bladder emptied.

For statistical data processing, descriptive and analytical statistics using SPSS 21.0 for Windows was utilised. Statistical significance was adopted at a probability level of $\mathrm{p}<0.05$.

\section{Results}

The sample consisted of 408 female students aged 19-22 who attended the summer semester of the 1st or 2nd year of the University of Banja Luka (2018/2019 school year). The results of this research were divided into several segments. 


\section{A. Results of a basic socio-demographic questionnaire}

A total of $37.7 \%$ of girls drink alcohol periodically, $19.8 \%$ regularly consume tobacco and 7.1 $\%$ use marijuana. The menstrual cycle was established at the earliest age of eight (0.7 \%) and at the latest at the age of twenty (0.2\%), while in $29.2 \%$ of cases it was established at the age of 13. From the demographic questionnaire, the question was: what is your current physical and mental health compared to the pre-study status? The following answers were received: $41.4 \%$ of students said that physical health was worse than at the beginning of studying and 45 $\%$ that mental health is now worse. The usage of psychostimulants was $0.2 \%$, hallucinogens 0.2 $\%$, sedatives $0.7 \%$, while $2.7 \%$ had a lifetime surgery.

\section{B. Results of the anthropological analysis of the sample}

The Kruskal-Wallis test confirmed that for all measured parameters there was a statistically

Table 1: Unhealthy behaviors adopted by the female students

\begin{tabular}{|c|c|c|c|}
\hline & & Frequency & Percent \\
\hline \multirow{3}{*}{$\begin{array}{l}\text { SELF-ASSESSMENT OF } \\
\text { PHYSICAL HEALTH } 1 \text { YEAR } \\
\text { LATER }\end{array}$} & a better & 32 & 7.8 \\
\hline & the same & 207 & 50.7 \\
\hline & a worse & 169 & 41.4 \\
\hline \multirow{3}{*}{$\begin{array}{l}\text { SELF-ASSESSMENT OF } \\
\text { MENTAL HEALTH } 1 \text { YEAR } \\
\text { LATER }\end{array}$} & a better & 40 & 9.8 \\
\hline & the same & 184 & 45.1 \\
\hline & a worse & 184 & 45.1 \\
\hline \multirow{2}{*}{ ALCOHOL CONSUMPTION } & yes & 154 & 37.7 \\
\hline & no & 254 & 62.3 \\
\hline \multirow{2}{*}{ TOBACCO CONSUMPTION } & yes & 81 & 37.7 \\
\hline & no & 327 & 62.3 \\
\hline \multirow{2}{*}{ MARIJUANA CONSUMPTION } & yes & 29 & 7.1 \\
\hline & no & 379 & 92.9 \\
\hline \multirow{2}{*}{$\begin{array}{l}\text { PROFESSIONAL } \\
\text { PSYCHIATRIC HELP }\end{array}$} & yes & 29 & 7.1 \\
\hline & no & 379 & 92.9 \\
\hline \multirow{2}{*}{ SUICIDAL ATTEMPT } & yes & 5 & 1.2 \\
\hline & no & 403 & 98.8 \\
\hline \multirow{2}{*}{$\begin{array}{l}\text { USE OF PSYCHOACTIVE } \\
\text { SUBSTANCE }\end{array}$} & yes & 1 & 0.2 \\
\hline & no & 407 & 99.8 \\
\hline \multirow{2}{*}{ USE OF SEDATIVES } & yes & 3 & 0.7 \\
\hline & no & 405 & 99.3 \\
\hline \multirow{2}{*}{ USE OF HALLUCINOGENS } & yes & 1 & 0.2 \\
\hline & no & 407 & 99.8 \\
\hline
\end{tabular}

significant difference ( $\mathrm{p} \geq 0.001$ ) in levels between 5 BMI categories except for body height (Table 1 and Table 2).

Based on the results of the descriptive analysis of demographic data, a description of a typical female student of the first two years of the University of Banja Luka was obtained as a person with an average height of $168.65 \pm 6.01 \mathrm{~cm}$ and a body mass of $63.09 \pm 9.9 \mathrm{~kg}$, which corresponds to a BMI value of $22.1 \pm 3.2 \mathrm{BMI}$, with body fat

Table 2: Descriptive statistics of the anthropometric characteristics of the sample

\begin{tabular}{|c|c|c|c|c|c|c|c|}
\hline & & $\mathbf{N}$ & Me & SD & Min & Max & ledi \\
\hline & age & 408 & & 2 & 19.0 & 22.0 & 20.00 \\
\hline & & 408 & & & 152.0 & 185.0 & 9.00 \\
\hline & & 408 & & 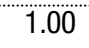 & 6 & 1 & .45 \\
\hline \multirow{3}{*}{$\begin{array}{l}\text { BMI TOTAL. } \\
\text { Corporal } \\
\text { Composition }\end{array}$} & tal & 408 & 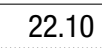 & .20 & 6.0 & 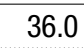 & .60 \\
\hline & fat & 408 & & 6.47 & 17.2 & 51.0 & 27.50 \\
\hline & uscule & 408 & 28.15 & 2.81 & 21.0 & 46.8 & 26.40 \\
\hline CATEGORY & & & & & & & \\
\hline \multirow{5}{*}{$\begin{array}{l}1 . \\
\text { BMI }(<18.5) \\
\text { Malnutrition }\end{array}$} & height & 33 & & 5.82 & .5 & H.U & 9.00 \\
\hline & & 33 & & 4.55 & 42.6 & 65.5 & 1.10 \\
\hline & $\mathrm{BMI}$ & 33 & 17.71 & 0.56 & 16.0 & 18.4 & 7.90 \\
\hline & 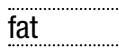 & 33 & & & 17.2 & 25.0 & 22.30 \\
\hline & 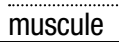 & 33 & & 4 & 27.9 & 34.7 & 30.40 \\
\hline \multirow{5}{*}{$\begin{array}{l}2 . \\
\text { BMI } \\
(18.5-24.9) \\
\text { Ideal mass }\end{array}$} & heig & 311 & 168 & 5.88 & 152.0 & 185.0 & 169.00 \\
\hline & & 311 & & 6.54 & 45.5 & 84.1 & 60.40 \\
\hline & BMII & 311 & 21 & 1.66 & 18.5 & 24.7 & 21.30 \\
\hline & fat & 311 & & ?... & 17.8 & 40.2 & 30.90 \\
\hline & mus & 311 & & 2.48 & 22.5 & 46.8 & 28.30 \\
\hline \multirow{5}{*}{$\begin{array}{l}3 . \\
\text { BMI } \\
(25-29.9) \\
\text { Overweight }\end{array}$} & height & 53 & 168 & 5.61 & 155.0 & 180.0 & 170.00 \\
\hline & & 53 & & 7.25 & 65.0 & 92.3 & 74.20 \\
\hline & & 53 & 26 & 1.43 & 25.0 & 29.8 & 0.0 \\
\hline & & 53 & 40 & 6 & 28.9 & 48.1 & 41.00 \\
\hline & $\mathrm{m}$ & 53 & 25.44 & 2.41 & 21.5 & 36.4 & 25.00 \\
\hline \multirow{5}{*}{$\begin{array}{l}4 . \\
\text { BMI } \\
(30-34.9) \\
\text { Mild obesity }\end{array}$} & & 8 & 162 & 11.35 & 152.0 & 173.0 & 165.00 \\
\hline & weig & 8 & 86.40 & 5.18 & 78.0 & 93.3 & 86.2 \\
\hline & BMI & 8 & 31.36 & 1.63 & 30.1 & 34.3 & 30.55 \\
\hline & fat & 8 & 43.66 & 6.97 & 28.3 & 50.9 & 45.20 \\
\hline & muscule & 8 & 23.83 & 1.73 & 21.5 & 26.7 & 23.45 \\
\hline \multirow{5}{*}{$\begin{array}{l}5 . \\
\text { BMI } \\
\text { (35-39.9) } \\
\text { Severe } \\
\text { obesity }\end{array}$} & & 3 & 167.66 & 5.69 & 163.0 & 174.0 & 166.00 \\
\hline & weight & 3 & 100 & 5.33 & 95.6 & 106.1 & 99.30 \\
\hline & BN & 3 & 35.67 & 0.58 & 35.0 & 36.0 & 36.00 \\
\hline & fat & 3 & 50.23 & 0.71 & 49.6 & 51.0 & 50.10 \\
\hline & muscule & 3 & 21.93 & 0.81 & 21.0 & 22.5 & 22.30 \\
\hline
\end{tabular}

of $31.80 \pm 6.47 \%$ and the proportion of muscle mass of $28.15 \pm 2.81 \%$. BMI categorisation by groups showed that there were $76.2 \%$ participants with an ideal body mass, while $0.7 \%$ were severely obese and $8.1 \%$ belonged to the malnourished population. The tallest students had the lowest BMI and accordingly had the lowest percentage of adipose tissue and the highest percentage of muscle tissue.

\section{Results of Sample Analysis by SF36 Scale} The Health Survey Questionnaire (SF-36) was used to assess the health status (Table 3 and Table 4). Descriptive analysis was calculated for eight 
health scales (physical functioning), the role of physical restraint, physical pain, general health, vitality, social functioning, the role of emotional restriction and mental health). The reliability of the SF-36 scale was analysed with an alpha Cronbach coefficient whose values ranged from 0.81 to 0.94, which indicated a very good reliability and internal agreement for this sample, with the exception of items of social functioning and general health whose alpha Cronbach values were 0.65

Table 3: BMI analysis (5 BMI categories) Kruskal-Wallis test

\begin{tabular}{llcccccc}
\hline & Height & Weight & BMI & FAT & \multicolumn{2}{c}{ Muscule Viscfat } \\
\hline CHI-SQUARE & 3.440 & 181.580 & 225.672 & 194.757 & 125.896 & 206.465 \\
DF & 4 & 4 & 4 & 4 & 4 & 4 \\
ASYMP. SIG. & 0.487 & 0.000 & 0.000 & 0.000 & 0.000 & 0.000 \\
\hline
\end{tabular}

and 0.69, respectively. Descriptive analysis of the SF-36 test (Table 3), which assesses 8 domains of health, shows that the lowest score has the Fatigue variable (mean $=50.10$; standard deviation - $\mathrm{SD}=17.83$ ), which refers to the feeling of fatigue compared to the previous year and indicates that students are often not "full of energy and life." The highest score is perceived pain ( mean $=77.57, \mathrm{SD}$ $=20.89$ ) and physical limitation (mean $=77.02$, $\mathrm{SD}=33.21)$.

The relationship between individual scores within the SF-36 questionnaire was investigated by using Spearman's rho non-parametric correlation. From Table 1 it can concluded that high statistical significance $(\mathrm{p}=0.001)$ with positive cor-

Table 4: Descriptive analysis of sample with SF-36 scale

\begin{tabular}{|c|c|c|c|c|c|c|}
\hline CRO & BACH A & Mean & SD & Min & Max & Median \\
\hline $\begin{array}{l}\text { PHYSICAL } \\
\text { FUNCTIONING }\end{array}$ & 0.948 & 73.90 & 32.50 & 0.00 & 100.00 & 90.00 \\
\hline $\begin{array}{l}\text { ROLE } \\
\text { FUNCTIONING/ } \\
\text { PHYSICAL }\end{array}$ & 0.813 & 77.02 & 33.21 & 0.00 & 100.00 & 100.00 \\
\hline $\begin{array}{l}\text { ROLE } \\
\text { FUNCTIONING/ } \\
\text { EMOTIONAL }\end{array}$ & 0.848 & 60.38 & 42.65 & 0.00 & 100.00 & 66.67 \\
\hline ENERGY/ FATIGUE & 0.805 & 50.10 & 17.83 & 0.00 & 100.00 & 55.00 \\
\hline $\begin{array}{l}\text { EMOTIONAL } \\
\text { WELL-BEING }\end{array}$ & 0.868 & 60.84 & 18.05 & 4.00 & 100.00 & 64.00 \\
\hline $\begin{array}{l}\text { SOCIAL } \\
\text { FUNCTIONING }\end{array}$ & 0.655 & 71.48 & 21.29 & 0.00 & 100.00 & 75.00 \\
\hline PAIN & 0.832 & 77.57 & 20.89 & 0.00 & 100.00 & 77.50 \\
\hline $\begin{array}{l}\text { GENERAL } \\
\text { HEALTH }\end{array}$ & 0.695 & 66.62 & 16.97 & 10.00 & 100.00 & 70.00 \\
\hline
\end{tabular}

relation among the variables were found for vital energy (fatigue) and mental health (emotions), with coefficient of determination $\mathrm{r}^{2}=0.55(55 \%)$ and mental health and social functioning with $\mathrm{r}^{2}$ $=0.36(36 \%)$. By using the Spearman nonparametric test (Table 4), the values of the correlation coefficient and the significance of the correlation were shown and the strength of the association between the subscales of the SF-36 questionnaire was determined. As expected, most of the correla-

Table 5: Spearman correlation of SF-36 questionnaire scores $(N=408)$

\begin{tabular}{|c|c|c|c|c|c|c|c|}
\hline SCORE SF-36 & 2 & 3 & 4 & 5 & 6 & 7 & 8 \\
\hline $\begin{array}{l}\text { PHYSICAL } \\
\text { FUNCTIONING }\end{array}$ & $\begin{array}{l}0.322 \\
* *\end{array}$ & 0.138 & 0.047 & 0.068 & $\begin{array}{l}0.109 \\
*\end{array}$ & 0.068 & $\begin{array}{l}0.177 \\
* *\end{array}$ \\
\hline $\begin{array}{l}\text { ROLE } \\
\text { FUNCTIONING/ } \\
\text { PHYSICAL }\end{array}$ & & $\begin{array}{l}0.364 \\
\star \star\end{array}$ & $\begin{array}{l}0.230 \\
* *\end{array}$ & $\underbrace{0.258}_{* *}$ & $\underset{* *}{0.338}$ & $\begin{array}{l}0.313 \\
* *\end{array}$ & ${ }_{* *}^{0.312}$ \\
\hline $\begin{array}{l}\text { ROLE } \\
\text { FUNCTIONING/ } \\
\text { EMOTIONAL }\end{array}$ & & & $\begin{array}{l}0.444 \\
\star \star\end{array}$ & $\begin{array}{l}0.455 \\
\star *\end{array}$ & $\begin{array}{l}0.461 \\
\star \star\end{array}$ & $\begin{array}{l}0.127 \\
\star\end{array}$ & ${ }_{* *}^{0.214}$ \\
\hline ENERGY/ FATIGUE & & & & 0.742 & 0.469 & 0.245 & 0.366 \\
\hline $\begin{array}{l}\text { EMOTIONAL } \\
\text { WELL-BEING }\end{array}$ & & & & & $\underset{* *}{0.595}$ & $\underset{* *}{0.223}$ & $\underset{* \star}{0.365}$ \\
\hline $\begin{array}{l}\text { SOCIAL } \\
\text { FUNCTIONING }\end{array}$ & & & & & & $\underset{\star \star}{0.272}$ & $\underset{* \star}{0.334}$ \\
\hline PAIN & & & & & & & 0.395 \\
\hline $\begin{array}{l}\text { GENERAL } \\
\text { HEALTH }\end{array}$ & & & & & & & \\
\hline
\end{tabular}

1 the table shows the values of the correlation coefficient ( $\mathrm{\rho})$ :

* Significance of correlation at 0.05 level

${ }^{\star *}$ Correlation significance at 0.01 level

tions showed a statistical significance of different levels, in a positive direction, given the fact that all subtrees belong to the same type of test, intended to reveal different aspects of the physical and mental health of the subjects. According to the value of the correlation coefficient, the essential clinical significance was shown primarily by the positive correlations of Vital energy (SF-36 fatigue) and Mental health (SF-36 emotions) ( $\rho=$ $0.742 ; \mathrm{p}<0.01$ ) as well as General mental health (SF-36 emotions) and Social functioning (SF-36 soc. funct.) $(\rho=0.595 ; p<0.01)$, which are also mental health categories. The absence of significant correlations was reported for Physical functionality paired with Near vital energy, Mental health and Pain. In the realm of physical health, the associated sub-axes: physical functioning, physical limitation, physical pain, and general health perception are low positive correlations with high statistical significance for $\mathrm{p}<0.05$, ex- 
cept for the sub-scores Physical functioning and Physical pain that do not have statistical significance.

\section{Discussion}

This research was aimed to demonstrate how and to what extent the initial years of studying at the university affect the health of female students through the aspect of self-assessment of physical and mental health as a significant moment in the life of a young woman. By going to college, students face the challenge of changing their previous habits in order to cope with the academic workload and stress that their schooling carries. This often implies lack of time for rest and sleep, physical and recreational activities, but also changed health habits leading to malnutrition, excessive alcohol consumption, smoking and consumption of psychoactive substances, which is confirmed in the current study. Psychostimulants were used by $0.2 \%$ of female students, hallucinogens by $0.2 \%$, sedatives by $0.7 \%$; while $35 \%$ of students drank alcohol periodically, tobacco was consumed by $15.9 \%$ regularly, while $7.1 \%$ used marijuana. In the Netherlands, the prevalence of smokers has been shown to be relatively low, only $6 \%$, but with $46 \%$ of students consuming alcohol and over $6 \%$ of students using stimulants, tranquilisers or sleeping remedies in the last 30 days. ${ }^{17}$ Among medical students in Germany there were $21 \%$ smokers, with $34 \%$ of students confirming the use of psychoactive substances. ${ }^{18}$ Research in Poland has shown that sixth-year medical students have a very cursory knowledge of the harmful health effects of alcohol consumption and smoking, with $26 \%$ of female students being smokers. ${ }^{19}$ A study conducted among students in Toulouse, France, also confirmed that approximately the same percentage of smokers among students in this European country was around $23 \%$. More than half of students use some of psychoactive substances. ${ }^{20}$ A study in Istanbul among students of the Faculty of Physical Activity and Sports showed that $25 \%$ were smokers and that at the age of 18 most girls started smoking. ${ }^{21}$

The results of the descriptive analysis of demographic parameters provided data on the anthropological characteristics of female students of the first two years of the University of Banja Luka. These are young persons, $20.5 \pm 0.7$ years old, averaged $168.65 \mathrm{~cm} \pm 6.01$ in height, $63.09 \pm 9.9 \mathrm{~kg}$ in body weight, corresponding to BMI $22.1 \pm 3.2 \mathrm{~kg} / \mathrm{m}^{2}$ and thus characterised as persons with an ideal BMI, which is a common result in studies by authors from neighbouring countries. ${ }^{22-28}$ The University of Banja Luka students are higher than their female counterparts in Canada, ${ }^{29}$ Greece, ${ }^{30},{ }^{31}$ and Croatia, ${ }^{23}$ while female students from Brazil are higher than the students from the University of Banja Luka. ${ }^{33}$ According to the measurements performed in this study, the proportion of adipose tissue was $31.80 \pm 6.47 \%$, ranging from $17.2 \%$ to $51 \%$ of the total body mass, while the mean values of muscle mass were $28.15 \pm 2.81 \%$, ranging from $21 \%$ to $36.80 \%$ of the total body mass. Similar research was carried out by Mašina (2019), ${ }^{23}$ where the average value of adipose tissue in the total sample of 596 girls of the same age was $20.36 \pm 6.66 \%$ (range 12.8-54.1\%). At the same time, the value of muscle mass was $28.80 \pm 3.35$ \% (range $13 \%$ to $42 \%$ ). In the present study, a detailed sample analysis indicated that there was a slight difference in the average value of body height compared to belonging to the BMI categories and that female students in the first BMI category had the highest body height. With the increase of BMI, as expected, the proportion of muscle mass was constantly decreasing and the values of all other parameters (body mass, presence of subcutaneous and visceral adipose tissue) were continuously increasing.

Self-assessment of health is the individual perception and evaluation of one's own health through standardised questionnaires. The SF-36 Health Survey Questionnaire was used to assess health status. Physical Health (PH) assessment covers the four scales of the SF-36 questionnaire, namely: physical functioning, physical limitations, physical pain, and general health. The calculated $\mathrm{PH}$ value (mean $\pm \mathrm{SD}$ ) was 72.21 \pm 25.89 . A high score that is appropriate for the student population implies a person's condition without restriction in performing daily activities and a person on this scale described their health as excellent. Assessment of Mental Health (MH) includes the remaining four scales of the SF-36 questionnaire: vitality, social functioning, the role of emotional restriction and mental health. This summary measure of MH had slightly lower value of $60.7 \pm 24.95$. This relatively lower 
score on this $\mathrm{MH}$ scale indicates the presence of psychological pain and significant limitations in social functioning, resulting in stress and a degree of psychological distress. A high score on the $\mathrm{MH}$ scale is more appropriate for the student population as it relates to a positive emotional state and complete social activities. Achieving a high score on this scale is associated with frequent feelings of happiness and life satisfaction and a person perceives their health as excellent. The "vitality" subscale, which is one of the sub-categories of SF-36, was the lowest in all subsamples, which may be a sign of population fatigue. ${ }^{34}$ Normative data for the SF-36 questionnaire are available in many countries. Compared to the SF-36 values of students from other countries, students who participated in this study had better SF-36 scores than students at a Turkish university (FH 66.54 $\pm 25.39 ; \mathrm{MH}$ $58.81 \pm 27.46) .{ }^{35} \mathrm{SF}-36$ scores of the female students that participated in this study were lower than those of the Belgrade University students (FH $78.4 \pm 14.0 ; \mathrm{MH} 68.6 \pm 19.1),{ }^{36}$ a university in Italy (FH $83.68 \pm 24.85 ; \mathrm{MH} 67.88 \pm 25.89)^{24}$, ${ }^{37}$ and a university in Croatia (FH $72.54 \pm 8,24$; MH 68.71 \pm 10.97). ${ }^{24}$

\section{Conclusion}

The results of the study of anthropological characteristics of the students showed the ideal values of the total BMI. A lower percentage of muscle mass indicates a possible lack of physical fitness. The results of the self-assessment of health show that this population of young women has higher values of physical health compared to mental health, which may be a reflection of stress and a degree of psychological distress during studies.

\section{Acknowledgements}

None.

\section{Conflict of interest}

None.

\section{References}

1. Erikson EH. Childhood and society. Reissue edition. London: WW Norton \& Company; 1993.

2. Sequeira C, Carvalho JC, Goncalves A, Nogueira MJ, Lluch-Canut T, Roldan-Merino J. Levels of positive mental health in Portuguese and Spanish nursing students. J Am Psychiatr Nurses Assoc 2019 May 23:1078390319851569. doi: 10.1177/1078390319851569.

3. Gulliver A, Farrer L, Bennett K, Griffiths KM. University staff mental health literacy, stigma and their experience of students with mental health problems. J Furth High Educ 2019;43(3):434-42.

4. Curković S. [Kinesiological activities and risky student behaviors]. [dissertation]. Zagreb: University of Zagreb; Faculty of Kinesiology, 2010. Croatian.

5. Wei CN, Harada K, Ueda K, Fukumoto K, Minamoto K, Ueda A. Assessment of health-promoting lifestyle profile in Japanese university students. Environ Health Prev Med 2012;17:222-7.

6. Zeng W, Chen R, Wang X, Zhang Q, Deng W. Prevalence of mental health problems among medical students in China: a meta-analysis. Medicine 2019 May;98(18), e15337. Doi: 10.1097/MD.0oooooooooo15337.

7. Russell K, Allan S, Beattie L, Bohan J, MacMahon K, Rasmussen S. Sleep problem, suicide and self-harm in university students: a systematic review. Sleep Med Rev 2019;44:58-69.

8. Mašina T, Madžar T, Musil V, Milošević M. Differences in health-promoting lifestyle profile among Croatian medical students according to gender and year of study. Acta Clin Croat 2017;56(1):84-91.

9. Wang D, Ou CQ, Chen MY, Duan N. Health-promoting lifestyles of university students in mainland China. BMC Public Health 2009 Oct 9;9:379. doi: 10.1186/1471-2458-9-379.

10. Thompson K, Wood D, MacNevin PD. Sex differences in the impact of secondhand harm from alcohol on student mental health and university sense of belonging. Addict Behav 2019;89:57-64.

11. Granja GL, Lacerda-Santos JT, de Moura Brilhante D, de Sousa Nóbrega Í, Granville-Garcia AF, Junior AD, et al. Smoking and alcohol consumption among university students of the healthcare area. J Public Health (Berl) 2020;28:45-52.

12. Adolescent mental health in the European Region. Geneva (CH): World Health Organization (WHO); 2018. [cited 2020 January 08]. Available from: http://www. euro.who.int/__data/assets/pdf_file/0005/383891/ adolescent-mh-fs-eng.pdf?ua $=1$,

13. Selimović A, Selimović LT, Husarić EE. [Self-esteem and study adjustment: do students with higher levels of self-esteem have better emotional, social and academic adjustment?]. Primen Psihol 2019;12(3):26381.

14. McDowell I. Measuring Health. A guide to Rating Scales and Questionnaires. 3rd ed. New York: Oxford University Press; 2006.

15. Maslić Seršić D, Vuletić G. Psychometric evaluation and establishing norms of Croatian SF-36 health sur- 
vey: framework for subjective health research. Croat Med J 2006;47(1):95-102.

16. 36-Item Short Form Survey (SF-36) Scoring Instructions. [internet] Santa Monica(USA): The RAND Corporation [cited 08.01.2020] Available from: https:// www.rand.org/health-care/surveys_tools/mos/36item-short-form/scoring.html.

17. Van der Veer T, Frings-Dresen MHW, Sluiter JK. Health Behaviors, care needs and attitudes towards self-prescription: a cross-sectional survey among Dutch medical students. PLoS One 2011;6(11):e28038. doi: 10.1371/journal.pone.0028038.

18. Voigt K, Twork S, Mittag D, Göbel A, Voigt R, Klewer $\mathrm{J}$, et al. Consumption of alcohol, cigarettes and illegal substances among physicians and medical students in Brandenburg and Saxony (Germany). BMC Health Serv Res 2009 Dec 3;9:219. doi: 10.1186/1472-69639-219.

19. Bielska D, Kurpas D, Marcinowicz L, Owłasiuk A, Litwiejko A, Wojtal M. [Evaluation of the risk of alcohol consumption and tobacco smoking among 6th year students of the Faculty of Medicine]. Przegl Lek 2012;69(10):900-3. Polish.

20. Sommet A, Ferrières N, Jaoul V, Cadieux L, Soulat JM, Lapeyre-Mestre M, et al. Use of drugs, tobacco, alcohol and illicit substances in a French student population. Therapie 2012;67(5):429-35.

21. Ulus T, Yurtseven E Donuk B. Prevalence of smoking and related risk factors among physical education and sports school students at Istanbul University. Int J Environ Res Public Health 2012;9(3):674-84.

22. Crnobrnja V, Sredić B, Stokić E, Dujmović D, Andrejić B. [Frequency analysis of risky forms of obesity in the University of Novi Sad students]. Med Pregl 2012;45(3-4):133-7. Serbian.

23. Mašina T. [Relationship between anthropometric characteristics, motor abilities, healthy habits and self-esteem among medical students] [dissertation]. Zagreb: University of Zagreb, Faculty of Medicine; 2019. Croatian.

24. Alić J. [The correlation between physical activity of female students, self-assessment of health and satisfaction with physical appearance]. [dissertation]. Zagreb: University of Zagreb, Faculty of Kinesiology; 2015. Croatian.

25. Ilić-Živojinović JB. [Analysis of the association between socio-environmental factors and academic stress with students' mental health]. [dissertation]. Belgrade: University of Belgrade, Faculty of Medicine; 2015. Serbian.
26. Smith C, Becnel J. Body Image, Self-esteem, and experiences of weight stigma, and fat bias in male and female young adults with varying BMI. Sutheastern Council on Family Relations Conference 2019 April; Sheraton Bentonville/Northwest, Arkansas;2019.

27. Fedewa MV, Nickerson BS, Esco MR. Associations of body adiposity index, waist circumference and body mass index in young adults. Clin Nutr 2019;38(2):7152.

28. Hong MY, Shepanski TL, Gaylis JB. Majoring in nutrition influences BMI of female college students. J Nutr Sci 2016 Feb 8;5:e8. doi: 10.1017/jns.2015.24.

29. Beaudry KM, Ludwa IA, Thomas AM, Ward WE, Falk B, Josse AR. First-year university is associated with greater body weight, body composition and adverse dietary changes in males than females. PloS One 2019 Jul 3;14(7):e0218554. doi: 10.1371/journal. pone.0218554.

30. Kintziou E, Nikolaidis PT, Kefala V, Rosemann T, Knechtle B. Validity of self-reported body mass, height, and body mass index in female students: the role of physical activity level, menstrual cycle phase, and time of day. Int J Environ Res Public Health 2019 Apr 3;16(7). pii: E1192. doi: 10.3390/ijerph16071192.

31. Papathanasiou G, Zerva E, Zacharis I, Papandreou M, Papageorgiou E, Tzima C, et al. Association of high bloood pressure with body mass index, smoking and physical activity in healthy young adults. Open Cardiovasc Med J 2015;9:5-17.

32. Han TS, Tijhuis MA, Lean ME, Seidell JC. Quality of life in relation to overweight and body fat distribution. Am J Public Health 1998;88(12):1814-20.

33. Silva B, Rodrigues LP, Clemente FM, Bezerra P, Cancela-Carral JM. Motor competence and body composition in young adults: an exploratory study. Obes Med 2019;14:e100087. doi: 10.1016/j.obmed.2019.100087.

34. Costa EF, Santos SA, Santos AT, Melo EV, Andrade TM. Burnout syndrome and associated factors among medical students: a cross-sectional study. Clinics (Sao Paulo) 2012;67(6):573-80.

35. Kitiş A, Büker N, Ünal A, Şavkın R. Effects of musculoskeletal system problems on quality of life and depression in students preparing for university entrance exam. Korean J Pain 2017;30(3):192-6.

36. Pekmezovic T, Popovic A, Tepavcevic DK, Gazibara T, Paunic M. Factors associated with health-related quality of life among Belgrade University students. Qual life Res 2011;20(3):391-7.

37. Messina G, Quercioli C, Troiano G, Russo C, Barbini E, Nisticò F, et al. Italian medical students quality of life: years 2005-2015. Ann Ig 2016;28(4):245-51. 